Creating Productive and Upcoming Sport Education Profesional Hmzanwadi University

Vol.3, No.2, Desember 2020, Hal. 149-158

e-ISSN 2614-8781

\title{
PERBANDINGAN KEMAMPUAN FISIK DASAR PETINJU NASIONAL DENGAN PETINJU DAERAH
}

\author{
Hegen Dadang Prayoga ${ }^{\mathbf{1}}$, Ari Tri Fitrianto ${ }^{2}$, Muhammad Habibie ${ }^{\mathbf{3}}$ \\ e-mail: newyoga0@gmail.com ${ }^{1}$, aritrifitrianto17@gmail.com ${ }^{2}$, habibiem789@ gmail.com ${ }^{3}$ \\ 1,2,3 Universitas Islam Kalimantan Muhammad Arsyad Al-Banjari Banjarmasin
}

\begin{abstract}
Abstrak
Fisik adalah salah satu faktor utama yang mempengaruhi penampilan atlet, khususnya dalam olahraga tinju. Minimnya prestasi yang diperoleh tim tinju Kalimantan Selatan ditingkat nasional, sudah tentu akan menjadi pemikiran bagi para pembina, pelatih, orang tua atlet dan semua yang terlibat didalamnya. Sehingga ditariklah suatu permasalahan pada penelitian ini adalah apakah ada perbandingan kemampuan fisik antara petinju nasional dengan petinju daerah di provinsi Kalimantan Selatan. Tujuan dari penelitian ini adalah untuk mengetahui apakah ada perbandingan kemampuan fisik antara petinju nasional dengan petinju daerah di Kalimantan Selatan. Berdasarkan hasil perhitungan uji hipotesis penelitian diperoleh hasil $-1,76<1,34<$ 1,76 atau $t_{\text {hitung }}=1,34$ terletak antara $-1,76$ dan 1,76 pada taraf nyata $\alpha=0,05$ sehingga hasil dari penelitian ini tidak ada perbedaan kemampuan fisik petinju nasional kalimantan selatan dengan kemampuan fisik petinju daerah kalimantan selatan yang artinya petinju di daerah provinsi kalsel mampu bersaing secara kemampuan fisik dengan petinju Kalimantan Selatan yang sudah berada dikancah Nasional dan terus tetap mengasah kemampuan teknik dan taktik serta mental.
\end{abstract}

Kata Kunci: Tinju, Kemampuan fisik

\section{Abstract}

Physical is one of the main factors affecting athlete's appearance, especially in boxing. The lack of achievements obtained by the South Kalimantan boxing team at the national level will certainly be a thought for the coaches, coaches, parents of athletes and all those involved in it. So that a problem is drawn in this study is whether the comparison of physical abilities between national boxers and regional boxers in South Kalimantan province. The purpose of this study was to determine whether there is a comparison of physical abilities between national boxers and regional boxers in South Kalimantan. Based on the results of the calculation of the research hypothesis test, the result is $-1.76<1.34<1.76$ or $t_{\text {count }}=1.34$ lies between -1.76 and 1.76 at the real level $\alpha=0.05$ so the results of this study There is no difference between the physical abilities of the South Kalimantan national boxers and the South Kalimantan boxers, which means that the boxers in the South Kalimantan province are able to compete physically with the South Kalimantan boxers who are already in the National arena and continue to hone their technical, tactical and mental abilities.

Keywords: Boxing, physical ability

Journal Pendidikan Jasmani Kesehatan \& Rekreasi (PORKES) |149 


\section{A. Pendahuluan}

Kejuaraan Tinju amatir yang sering digelar merupakan salah satu tolak ukur untuk mengetahui sejauh mana pembinaan cabang olahraga tinju amatir di masing-masing daerah. Akhir-akhir ini prestasi tim tinju amatir Kalimantan Selatan belum pernah menjadi juara umum dalam mengikuti kejuaraan nasional. Minimnya prestasi yang diperoleh tim tinju Kalimantan Selatan ditingkat nasional, sudah tentu akan menjadi pemikiran bagi para Pembina, pelatih, orang tua atlet dan semua yang terlibat didalamnya. Salah satu faktor yang perlu diketahui dengan segera adalah tingkat kemampuan fisik atlet karena kemampuan fisik seorang atlet dapat dikatakan sebagai keadaan yang memberikan ciri tentang derajat atau tingkat kemampuan seseorang di dalam melakukan kegiatan, baik itu kegiatan dalam bertanding maupun dalam berlatih. "Oleh karena itu kata kunci untuk mencapai prestasi dan keunggulan dalam olahraga adalah berlatih dan prestasi'" (Harsuki, 2003:364). Prestasi puncak dalam olahraga jarang dicapai secara kebetulan. Tercapainya Prestasi puncak adalah hasil dari persiapan atlet yang amat cermat, berdasarkan program latihan yang terorganisasi secara rinci, direncanakan secara bertahap, obyektif, dan diterapkan secara berkesinambungan. Akibat dari perencanaan yang matang itulah bahwa kualitas latihan akan naik sehingga akan meningkatkan pula kapasitas kerja atlet serta keterampilannya. Prestasi puncak merupakan hasil langsung dari adaptasi atlet terhadap berbagai sistem, metode, dan bentuk latihan. Berkaitan dengan hal tersebut diatas, sebagai atlet tinju amatir Kalimantan Selatan perlu kiranya untuk mengetahui apakah ada perbandingan kemampuan fisik antara petinju daerah dengan petinju nasional di Kalimantan Selatan. Karena para ahli sepakat bahwa "hanya atlet yang memiliki kemampuan fisik prima yang mampu berlatih secara optimal.Dan hanya atlet yang berlatih secara optimal yang memungkinkan perolehan prestasi optimal pula“. (Moch Moeslim,dalam Harsuki,2003:318). Permasalahan dominan dalam penelitian ini adalah ada atau tidaknya perbandingan kemampuan fisik antara petinju daerah dengan petinju amatir yang berada di Kalimantan Selatan. Petinju daerah yang belum pernah berada di level nasional apakah mampu bersaing dengan para petinju yang pernah ataupun sering bermain di level nasional. Apabila para petinju daerah tersebut mampu bersaing dengan petinju nasional salah satunya adalah kemampuan fisiknya maka persaingan antara petinju daerah dengan petinju nasional akan semakin ketat sehingga akan semakin banyak generasi yang dimiliki Pengprov PERTINA Kalimantan Selatan. Untuk saat ini generasi petinju di Kalimantan Selatan hanya sedikit dikarenakan kalah bersaing dengan petinjupetinju daerah yang memiliki keuangan dan fasilitas lengkap seperti kota Banjarmasin yang mempunyai peralatan,tempat yang memadai karena jarak lokasi dekat dengan tempat latihan Pengprov Kalimantan Selatan. Oleh karena itu di cabang olahraga tinju,kemampuan fisik petinju merupakan salah satu unsur yang dapat menentukan pencapaian kualitas latihan secara maksimal. Sudah selayaknya harus diketahui kemampuan fisik petinju daerah dengan petinju nasional agar dapat menjadi bahan masukan dalam mengembangkan upaya peningkatan kualitas sumber daya manusia khususnya. Demikian pula dengan diketahuinya tingkat kemampuan fisik petinju amatir maka kualitas petinju akan dapat ditingkatkan, mengingat kemampuan fisik petinju merupakan salah satu pondasi utama yang harus dimiliki setiap petinju dalam melakukan latihan untuk dapat meraih prestasi puncak, karena tujuan kedepan setiap petinju adalah ingin menggapai prestasi setinggi mungkin bukan hanya di level daerah melainkan di level nasional maupun internasional.

\section{B. Metode}

Metode yang digunakan dalam penelitian ini adalah metode exfost facto dengan teknik pengumpulan data melalui tes dan pengukuran. Adapun populasi dalam penelitian ini, di Pengda 
Pertina Kalimantan Selatan berjumlah 35 orang. Sampel adalah Petinju nasional dan petinju daerah berjumlah 16 orang. Teknik pengambilan sampel dilakukan dengan Purposive Sampling ".Sedangkan teknik pengumpulan data pada penelitian ini adalah:

1. Tahap persiapan

2. Tahap pelaksanaan yaitu tahap pengambilan data dengan cara melakukan tes dan pengukuran, yang diukur antara lain:

a. Dalam pelaksanaan tes kemampuan fisik cabang olahraga Tinju dibagi

b. Menjadi 8 item tes yaitu:
1) Lari 30 meter
5) Loncat dada
2) Sit-Up
3) Pull-u
4) Duduk pada tembok
6) Duduk berlunjur dan meraih
7) Lari bolak-balik4x5 meter
8) Lari 15 menit (balke)

3. Rancangan Analisis Data.

Untuk rancangan analisis data yang digunakan dalam penelitian ini melalui beberapa tahapan, yaitu meliputi:

1. Uji Runtun dengan uji Acak

2. Uji normalitas dengan uji Liliefors

3. Uji homogenitas dengan uji Bartlete

4. Uji hipotesis yaitu menguji dua rata-rata dengan uji dua pihak

(Sudjana 1992 : 261-265, 446-468)

$\mathrm{H}_{\mathrm{o}}: \mu \mathrm{X}_{1}: \mu \mathrm{X}_{2}=0$

$\mathrm{H}_{\mathrm{i}}: \mu \mathrm{X}_{1}: \mu \mathrm{X}_{2} \neq 0$

Sedangkan rumus statistik yang digunakan adalah uji t yaitu

$$
\begin{aligned}
& t=\frac{\overline{\mathrm{x}}_{1}-\overline{\mathrm{x}}_{2}}{\mathrm{~s} \sqrt{\frac{1}{\mathrm{n}_{1}} \div \frac{1}{\mathrm{n}_{2}}}} \quad \text { (Sudjana, 1992:239) } \\
& \mathrm{s}^{2}=\frac{\left(\mathrm{n}_{1}-1\right) \mathrm{s}_{1}^{2} \div\left(\mathrm{n}_{2}-1\right) \mathrm{s}_{2}^{2}}{\mathrm{n}_{1} \div \mathrm{n}_{2}-2}
\end{aligned}
$$

Kriteria uji: "Terima $\mathrm{H}_{\mathrm{o}}$ jika $-\mathrm{t}_{1}-1 / 2 \alpha<\mathrm{t}<\mathrm{t}_{1}-1 / 2 \alpha$ dimana $\mathrm{t}_{1}-1 / 2 \alpha$ didapat dari daftar distribusi t dengan $\mathrm{dk}=\left(\mathrm{n}_{1}+\mathrm{n}_{2}-2\right)$ dan peluang $\left(\mathrm{t}_{1}-1 / 2 \alpha\right)$. Untuk harga-harga $\mathrm{t}$ lainnya ho ditolak" (Sudjana, 1992:239-240)

Keterangan:

$\mathrm{H}_{\mathrm{o}} \quad$ : Hipotesis nol

$\mathrm{H}_{\mathrm{i}} \quad$ : Hipotesis alternatif

$\mu \mathrm{X}_{1} \quad$ : Rata-rata kemampuan fisik petinju daerah

$\mu \mathrm{X}_{2} \quad$ : Rata-rata kemampuan fisik petinju nasional

$\mathrm{n}_{1} \quad$ : Sampel 1

$\mathrm{s}_{1}{ }^{2}$ : Varians sampel 1

$\mathrm{n}_{2} \quad$ : Sampel 2

$\mathrm{s}_{2}{ }^{2}$ : Varians sampel 2

$\mathrm{t} \quad$ : $\mathrm{t}$ hitung 
s : Simpangan

\section{Hasil dan Pembahasan}

Hasil

Data nilai yang diperoleh dari hasil Tes Kemampuan Fisik Petinju Nasional dan Petinju Daerah Kalimantan Selatan didiskripsikan pada tabel data dibawah ini:

Tabel 1. Nama dan Skor Tes Kemampuan Fisik Petinju Nasional dan Petinju Daerah Kalimantan Selatan serta klasifikasi tingkat kemampuan Fisik Petinju Nasional dan Petinju Daerah Kalimantan Selatan.

\begin{tabular}{|c|c|c|c|c|c|c|}
\hline \multirow[b]{2}{*}{ No } & \multicolumn{3}{|c|}{ Petinju Nasional Kalimantan Selatan } & \multicolumn{3}{|c|}{ Petinju Daerah Kalimantan Selatan } \\
\hline & Nama & $\begin{array}{l}\text { Skor } \\
\text { Nilai }\end{array}$ & Klasifikasi & Nama & $\begin{array}{l}\text { Skor } \\
\text { Nilai }\end{array}$ & Klasifikasi \\
\hline 1 & AA & 3.4 & Sedang + & AR & 2.8 & Sedang - \\
\hline 2 & $\mathrm{BP}$ & 3.4 & Sedang + & EBS & 4.2 & Baik \\
\hline 3 & $\mathrm{~F}$ & 2.9 & Sedang - & FR & 3.1 & Sedang \\
\hline 4 & HK & 3.8 & Baik - & FR & 3.0 & Sedang \\
\hline 5 & $\mathrm{HP}$ & 3.4 & Sedang + & HP & 3.1 & Sedang \\
\hline 6 & JR & 3.4 & Sedang + & MSH & 2.2 & Kurang \\
\hline 7 & MI & 3.6 & Sedang + & $\mathrm{MZ}$ & 3.5 & Sedang + \\
\hline 8 & $\mathrm{TP}$ & 3.4 & Sedang + & PR & 2.9 & Sedang - \\
\hline & Jumlah & 27.3 & \multirow{3}{*}{ Sedang + } & Jumlah & 24.8 & \multirow{3}{*}{ Sedang - } \\
\hline & Rata-rata & $\begin{array}{l}3.4 \\
0.5\end{array}$ & & Rata-rata & $\begin{array}{c}3.1 \\
0.58\end{array}$ & \\
\hline & Standar deviasi & 0.25 & & Standar deviasi & 0.58 & \\
\hline
\end{tabular}

Keterangan:

$\begin{array}{ll}\mathrm{BS}+ & =\text { Baik Sekali }(\text { Plus }) \\ \mathrm{BS} & =\text { Baik Sekali } \\ \mathrm{B}+ & =\text { Baik }(\text { Plus }) \\ \mathrm{B} & =\text { Baik } \\ \mathrm{B}- & =\text { Baik }(\text { Min }) \\ \mathrm{S}+ & =\text { Sedang ( Plus ) } \\ \mathrm{S} & =\text { Sedang }\end{array}$

$$
\begin{array}{ll}
\mathrm{S}- & =\text { Sedang }(\text { Min ) } \\
\mathrm{K}+ & =\text { Kurang ( Plus ) } \\
\mathrm{K} & =\text { Kurang } \\
\mathrm{K}- & =\text { Kurang ( Min ) } \\
\mathrm{KS}+ & =\text { Kurang Sekali ( Plus ) } \\
\mathrm{KS} & =\text { Kurang Sekali }
\end{array}
$$

Hasil Tes Kemampuan Fisik Petinju Nasional Kalimantan Selatan (X1) Skor tertinggi adalah 3.8 dan nilai terendah 2.9, nilai rata-rata adalah 3.4 dengan standar deviasi 0.25. Selanjutnya data hasil Tes Kemampuan Fisik Petinju Daerah Kalimantan Selatan (X2) diperoleh nilai tertinggi adalah 4.2 dan nilai terendah 2.2, nilai rata-rata 3.1 dengan standar deviasi 0.58. Hasil lengkap dari item Tes Kemampuan Fisik Petinju Nasional dan Petinju Daerah Kalimantan Selatan dapat dilihat pada lampiran 19 dan lampiran 20 Hasil pengklasifikasian tingkat kemampuan Fisik Patinju Nasional dan Petinju Daerah Kalimantan Selatan didiskripsikan pada tabel 5 berikut ini: 
Tabel 2. Klasifikasi tingkat kemampuan Fisik Petinju Nasional dan Petinju Daerah Kalimantan Selatan

Petinju Nasional Petinju Daerah

\begin{tabular}{llll}
\hline Klasifikasi & Jumlah & Klasifikasi & Jumlah \\
\hline Baik Sekali + & - & Baik Sekali + & - \\
Baik Sekali & - & Baik Sekali & - \\
Baik + & - & Baik + & - \\
Baik & - & Baik & 1 orang \\
Baik - & 1 orang & Baik - & - \\
Sedang + & 6 orang & Sedang + & - \\
Sedang & - & Sedang & 4 Orang \\
Sedang - & 1 Orang & Sedang - & 2 Orang \\
Kurang + & - & Kurang + & - \\
Kurang & - & Kurang & 1 Orang \\
Kurang - & - & Kurang - & - \\
Kurang Sekali + & - & Kurang Sekali + & - \\
Kurang Sekali - & - & Kurang Sekali - & - \\
\hline
\end{tabular}

Pengujian persyaratan analisis yang dilakkukan meliputi uji runtun dengan uji acak uji, normalitas dan uji homogenitas.

a) Uji Runtun dengan uji Acak.

Langkah awal uji keacakan adalah data hasil tes dilapangan diurutkan dari yang tinggi ke rendah untuk mencari median (Me), kemudian data yang lebih tinggi dari Me diberi tanda (+) dan yang kurang dari Me diberi tanda (-), data yang digunakan dalam perhitungan adalah tingkat Kemampuan Fisik Petinju Nasional dan Petinju Daerah Kalimantan Selatan. Adapun urutan data dan median adalah sebagai berikut:

$$
\begin{aligned}
& \begin{array}{ccc}
2.2 & 2.8 & 2.9 \\
3.4 & 3.4 & 3.4 \\
=\frac{3.1+3.4}{2}= & 3.25
\end{array} \\
& \mathrm{n}_{1}-=7 \\
& \mathrm{n}_{1+}=9 \\
& \mathrm{U}=8
\end{aligned}
$$

Hipótesis: Ho = Sampel diambil dari populasinya secara acak. $\mathrm{Hi}=$ Sampel diambil dari populasinya secara tidak acak.

Kriteria: Tolak Ho bila U hitung terletak di luar U tabel dalam hal lain terima Ho. Kesimpulan: Hasil uji acak $U$ hitung $=8$, sedangkan $U$ tabel (4-14), Jadi $U$ hitung terleta di antara $U$ tabel dengan demikian sampel diambil dari populasinya secara acak. Hasil pengujian dengan uji runtun dapat dilihat pada lampiran. 
b) Uji Normalitas dengan uji Lilliefors.

Untuk menerima atau menolak $\mathrm{H}_{\mathrm{o}}$ tersebut yaitu dengan membandingkan harga mutlak $\mathrm{L}$ hasil perhitungan $\left(\mathrm{L}_{\mathrm{o}}\right)$ dengan harga mutlak $\mathrm{L}$ tabel $\left(\mathrm{L}_{\mathrm{t}}\right)$ pada taraf signifikansi $\alpha=$ 0,05. Kriteria uji: "tolak hipotesis nol bahwa populasi berdistribusi normal jika $\mathrm{L}_{\mathrm{o}}$ yang diperoleh dari data pengamatan atau perhitungan melebihi L dari daftar. Dalam hal lainnya hipotesis nol diterima" Uji normalitas tingkat kemampuan Fisik Petinju Nasional Kalimantan Selatan $\left(\mathrm{X}_{1}\right)$ dan tingkat kemampuan Fisik Petinju Daerah Kalimantan Selatan $\left(\mathrm{X}_{2}\right)$ tertera pada tabel dibawah ini:

Tabel 3. Hasil Uji Normalitas tingkat Kemampuan Fisik Petinju Nasional Kalimantan Selatan $\left(\mathrm{X}_{1}\right)$ dan tingkat Kemampuan Fisik Petinju Daerah Kalimantan Selatan $\left(\mathrm{X}_{2}\right)$.

\begin{tabular}{clccc} 
Variabel & \multicolumn{1}{c}{ Hipotesis } & $\mathrm{L}_{\mathrm{o}}$ & $\mathrm{L}_{\mathrm{t}(\alpha=0,05 \mathrm{n}=8)}$ & Kesimpulan \\
\hline $\mathrm{X}_{1}$ & $\mathrm{H}_{\mathrm{o}}:$ Populasi berdistribusi normal & 0,2500 & 0,285 & Terima $\mathrm{H}_{\mathrm{o}}$ \\
& $\mathrm{H}_{\mathrm{i}}:$ : Populsi tidak berdistribusi normal & & & \\
$\mathrm{X}_{2}$ & $\mathrm{H}_{\mathrm{o}}:$ : Populasi berdistribusi normal & 0,2500 & \multirow{2}{*}{0,285} & Termal) \\
& $\mathrm{H}_{\mathrm{i}}:$ : Populsi tidak berdistribusi normal $\mathrm{H}_{\mathrm{o}}$ \\
\end{tabular}

Keterangan: $\mathrm{X}_{1}=$ Variabel tingkat Kemampuan Fisik Petinju Nasional

$\mathrm{X}_{2}=$ Variabel tingkat Kemampuan Fisik Petinju Daerah

$\mathrm{H}_{\mathrm{o}}=$ Hipotesis nol

$\mathrm{H}_{\mathrm{i}}=$ Hipotesis alternatif

$\mathrm{L}_{\mathrm{o}}=$ Harga $\mathrm{L}$ hasil pengamatan atau perhitungan

$\mathrm{L}_{\mathrm{t}}=$ Harga multak L tabel

c) Uji Homogenitas

Untuk menguji homogenitas digunakan uji Bartlett Uji homogeitas dalam penelitian ini adalah menguji homogenitas gabungan varians populasi, hipotesis yaitu $\mathrm{H}_{\mathrm{o}}: \sigma_{1}{ }^{2}=\sigma_{2}{ }^{2}$ atau $\mathrm{H}_{\mathrm{i}}: \sigma_{1}{ }^{2} \neq \sigma_{2}{ }^{2}$. Kriteria pengujian: "tolak hipotesis $\mathrm{H}_{\mathrm{o}}$ jika $\chi^{2} \geq \chi^{2}(1-\alpha)(\mathrm{k}-1)$, dimana $\chi^{2}$ $(1-\alpha)(\mathrm{k}-1)$ didapat dari daftar distribusi chi-kuadrat dengan peluang $(1-\alpha)$ dan $\mathrm{dk}=(\mathrm{k}-1)$ " Hasil uji homogenitas gabungan varians populasi tertera pada tabel berikut ini:

Tabel 4. Hasil Uji Homogenitas Gabungan Varians Populasi.

\begin{tabular}{ccccc} 
Hipotesis & $\chi^{2}$ & $\chi_{\mathrm{t}}^{2}(\alpha=0,05)(\mathrm{dk}=1)$ & Kesimpulan \\
\hline $\mathrm{H}_{\mathrm{o}}: \sigma_{1}{ }^{2}=$ & $\sigma_{2}{ }^{2}$ & 4.46 & 5,99 & Terima $\mathrm{H}_{\mathrm{o}}($ Homogen $)$ \\
$\mathrm{H}_{\mathrm{i}}: \sigma_{1}{ }^{2} \neq \sigma_{2}{ }^{2}$ & & & \\
\hline
\end{tabular}

Keterangan:

$\begin{array}{ll}\mathrm{H}_{\mathrm{o}} & =\text { Hipotesis nol } \\ \mathrm{H}_{\mathrm{i}} & =\text { Hipotesis alternatif } \\ \sigma_{1}{ }^{2} & =\text { Varians Tingkat Kemampuan Fisik Petinju Nasional } \\ \sigma_{2}{ }^{2} & =\text { Varians Tingkat Kemampuan Fisik Petinju Daerah } \\ \chi_{\mathrm{o}}{ }^{2} & =\text { Chi-kuadrat hitung } \\ \chi_{\mathrm{t}(\alpha=0,05)(\mathrm{dk}=1)}=\text { Chi-kuadrat tabel }\end{array}$


$\mathrm{dk} \quad=$ derajat kebebasan

d) Pengujian Hipotesis

Untuk mendapatkan kesimpulan dari penelitian ini adalah dengan menggunakan perhitungan statistik, yaitu melakukan uji dua rata-rata dengan membandingkan nilai t yang diperoleh dari perhitungan dengan nilai tabel. Menguji perbandingan tingkat Kemampuan Fisik Petinju Nasional $\left(\mathrm{X}_{1}\right)$ dengan tingkat Kemampuan Fisik Petinju Daerah $\left(\mathrm{X}_{2}\right)$ atau untuk menguji hipotesis penelitian yaitu sebagai berikut: Hipotesis: $\mathrm{H}_{0}: \mu \mathrm{X}_{1}: \mu \mathrm{X}_{2}=0 \mathrm{H}_{\mathrm{i}}$ : $\mu \mathrm{X}_{1}: \mu \mathrm{X}_{2} \neq 0$. Kriteria pengujian: “ Terima $\mathrm{H}_{\mathrm{o}}$ jika $\mathrm{t}<\mathrm{t}_{1-\alpha}$ dan tolak Ho jika $\mathrm{t}$ mempunyai harga-harga lain. Derajat kebebasan untuk daftar distribusi t ialah $\left(\mathrm{n}_{1}+\mathrm{n}_{2}-2\right)$ dan peluang $(1-\alpha)$ " (Sudjana, 1992:243). Hasil uji hipotesis penelitian seperti tertera pada tabel di bawah ini:

Tabel 5. Hasil uji hipotesis perbandingan tingkat Kemampuan Fisik Petinju Nasional $\left(\mathrm{X}_{1}\right)$ dengan tingkat Kemampuan Fisik Petinju Daerah $\left(\mathrm{X}_{2}\right)$.

\begin{tabular}{cccc} 
Hipotesis & $\mathrm{t}_{\mathrm{o}}$ & $\mathrm{t}_{\mathrm{t}(0,05)(\mathrm{dk}=14)}$ & Kesimpulan \\
\hline $\mathrm{H}_{\mathrm{o}}: \mu \mathrm{X}_{1}: \mu \mathrm{X}_{2}=0$ & 1,34 & 1,76 & Terima $\mathrm{H}_{\mathrm{o}}$ \\
$\mathrm{H}_{\mathrm{i}}: \mu \mathrm{X}_{1}: \mu \mathrm{X}_{2} \neq 0$ & & & (Tidak ada perbedaan) \\
\hline
\end{tabular}

Keterangan:

$\begin{array}{ll}\mathrm{H}_{\mathrm{o}} & =\text { Hipotesis nol } \\ \mathrm{H}_{\mathrm{i}} & =\text { Hipotesis alternatif } \\ \mu \mathrm{X}_{1} & =\text { Rata-rata tingkat Kemampuan Fisik Petinju Nasional } \\ \mu \mathrm{X}_{2} & =\text { Rata-rata tingkat Kemampuan Fisik Petinju Daerah } \\ \mathrm{t}_{\mathrm{o}} & =\text { Harga } \mathrm{t} \text { hasil perhitungan } \\ \mathrm{t}_{\mathrm{t}(0,05)(\mathrm{dk}=14)} & =\text { Harga } \mathrm{t} \text { tabel } \\ \mathrm{dk} & =\text { derajat kebebasan }\end{array}$

Berdasarkan hasil perhitungan uji hipotesis diketahui $\mathrm{t}(0,95)$ dengan $\mathrm{dk}=14$ dari daftar distribusi sudut adalah 1,76 sehingga diterima Ho karena to $=1,34$ terletak antara $-1,76$ dan 1,76". Dengan demikian dapat disimpulkan tidak ada perbedaan antara tingkat Kemampuan Fisik Petinju Nasional (X1) dengan tingkat Kemampuan Fisik Petinju Daerah (X2). Hasil perhitungan uji hipotesis secara lengkap dapat dilihat pada Lampiran. Pembahasan Hasil Penelitian Proses pelaksanaan penelitian ini, dimulai dari pengajuan proposal, seminar, pengurusan perizinan, pengambilan data kemampuan fisik sampai pada perhitungan statistik menggunakan kalkulator dan komputer dalam menganalisis data. Setelah dilaksanakan pengambilan data tingkat kemampuan fisik petinju melalui instrumen Tes Kemampuan fisik petinju dapat diperoleh data tingkat kemampuan fisik petinju Nasional dan tingkat kemampuan fisik Daerah. Selanjutnya dilakukan uji persyaratan analisis dengan menggunakan uji runtun, uji normalitas dan uji homogenitas. Setelah pengujian persyaratan dipenuhi, maka dilaksanakan pengujian hipotesis penelitian dengan melakukan uji dua rata-rata atau uji dua pihak dengan membandingkan nilai $t$ yang diperoleh dari perhitungan dengan nilai t pada tabel. Hasil yang diperoleh adala $-1,76<$ $1,34<1,76$ atau $t_{\text {hitung }}=1,34$ terletak antara $-1,76$ dan 1,76 pada tarap nyata 0,05 sehingga 
dapat disimpulkan tidak terdapat perbedaan antara tingkat kemampuan fisik petinju Nasional dengan petinju Daerah Kalimantan Selatan. Sehinga bisa disimpulkan berdasarkan hasil perhitungan uji hipotesis penelitian diperoleh hasil $-1,76<1,34<1,76$ atau t hitung = 1,34 terletak antara $-1,76$ dan 1,76 pada taraf nyata $\alpha=0,05$ sehingga dapat disimpulkan tidak ada perbedaan antara Kemampuan Fisik Petinju Nasional Kalimantan Selatan dengan Kemampuan Fisik Petinju Daerah Kalimantan Selatan.

Pembahasan

a) Pengertian kemampuan fisik

Kemampuan yaitu sanggup melakukan sesuatu (kamus besar bahasa indonesia:157) sedangkan fisik yaitu dartikan dengan badan, tubuh (kamus besar bahasa indonesia:75) jadi berbicara tentang kemampuan fisik dapat diartikan dengan badan atau tubuh yang sanggup melakukan sesuatu. Kemampuan fisik merupakan kebutuhan dasar dalam penampilan olahraga tinju dan kemampuan fisik juga harus dipertimbangkan sebagai bagian penting untuk menampilkan teknik dan taktik yang sempurna. Menurut Moch Moeslim dalam Harsuki (2003:318) “Acuan lainnya ada empat aspek kemampuan fisik yang harus dipenuhi untuk setiap cabang olahraga yaitu kecepatan, kekuatan, daya tahan, dan kelentukan atauy flexibilitas. dari aspek-aspek dominan dan empat kemampuan fisik dasar tersebut diolah menjadi butir-butir tes" Berbicara mengenai kemapuan fisik, maka persepsinya adalah badan yang sanggup melakukan sesuatu. banyak cara yang dapat ditempuh untuk mendapatkannya, salah satu diantaranya adalah dengan berolahraga. Oleh karena itu olahraga dapat dijadikan sebagai bagian dari kehidupan, sehingga tidak salah apabila orang mengatakan jangan harap kondisi fisik menjadi optimal dan tetap segar jika tubuh tidak aktif bergerak. Fisik yang tidak aktif bergerak akan merangsang tubuhnya menjadi hipokinetik. Komponen kemampuan fisik terdiri dari kelenturan, kecepatan gerak (dalam bentuk speed, agility maupun quickness), kekuatan maksimal, kekuatan yang cepat (power), daya tahan kekuatan, daya tahan anaerob, dan juga daya tahan aerob, semua komponen fisik tersebut pada prinsipnya merupakan kemampuan dinamis aerobik dan aerobik dalam olahraga tinju.

b) Data petinju daerah dengan petinju nasional

Petinju daerah adalah petinju yang ada di kalimantan selatan dan hanya mengikuti pertandingan-pertandingan di tingkat provinsi Kalimantan Selatan seperti Kejurprov, Porprov ataupun bupati cup dan belum pernah sekalipun mengikuti pertandingan di tingkat nasional seperti kejurnas, Prapon, PON dan kejuaran nasional lainnya. Sedangkan petinju nasional adalah petinju yang sudah pernah mengikuti kejuaraan nasional seperti kejurnas, STE, Prapon dan PON sehingga peniliti akan membandingkan kemampuan fisik petinju daerah dengan petinju nasional di Kalimantan Selatan dan buku rekor (record book).

\section{Kesimpulan}

Kemampua fisik petinju nasional dengan petinju daerah di Kalimantan Selatan berdasarkan hasil perhitungan uji hipotesis penelitian dapat disimpulkan tidak ada perbedaan antara Kemampuan Fisik Petinju Nasional Kalimantan Selatan dengan Kemampuan Fisik Petinju Daerah Kalimantan Selatan. Itu artinya ada peluang bagi para petinju daerah untuk dapat bersaing di level nasional mengingat faktor fisik paling dominan dalam olahraga tinju, sehingga perlu tambahan penguasaan teknik, taktik dan mental untuk dapat bersaing menuju level nasional. 
Creating Productive and Upcoming Sport Education Profesional Hmzanwadi University Vol.3, No.2, Desember 2020, Hal. 149-158

e-ISSN 2614-8781

\section{Daftar Pustaka}

Anton Hermawan. (2012)."Perbandingan ketepatan shoting kegawang menggunakan kaki bagian dalam dan kaki bagian luar pada tim sepak bola Banjarbaru”: Jurusan Pendidikan Olahraga dan Kesehatan FKIP UNLAM.

Abdurrojak, H., \& Imanudin, I. (2016). Hubungan Antara Reaction Time dan Kekuatan Maksimal Otot Lengan dengan Kecepatan Pukulan pada Cabang Olahraga Tinju. Jurnal Terapan Ilmu Keolahragaan, 1(2), 53-58.

Arikunto, S. 2002. Prosedur Penelitian Suatu Pendekatan Praktek. Jakarta: PT. Rineka Cipta.

Bafirman, B., \& Wahyuri, A. S. (2019). Pembentukan Kondisi Fisik.

Cahyanto, N. (2016). Rancang Bagun Sarung Tinju Berbasis Arduino Sebagai Alat Informasi Kemampuan Petinju Dalam Kegiatan Pelatihan (Doctoral Dissertation, Universitas Negeri Jakarta).

Djoko Lelono. (2004). "Evaluasi Pengajaran Pendidikan Jasmani". Banjarbaru: Jurusan Pendidikan Olahraga dan Kesehatan FKIP UNLAM. edu/Direktori/FPOK/JUR._PEND._OLAHRAGA/1965).

De Osmon, K., \& Sin, T. H. (2019). Tinjauan Kemampuan Kondisi Fisik Atlet Tinju PERTINA Kabupaten Tanah Datar. Jurnal Patriot, 1(1), 64-69.

Edy D.P Duhe. (2012). "Pengaruh pelatihan shadow boxing dengan metode interval Terhadap peningkatan Kapasitas aerobik maksimal (Studi Pada Petinju Sasana FIKK Universitas Negeri Gorontalo)": Gorontalo. Universitas Negeri Gorontalo.

Harsuki. (2003). "Perkembangan Olahraga Terkini. Kajian Para Pakar". Jakarta: Raja Grafindo Persada.

Hadi, U. (2015). Pertanggungjawaban Pidana Terhadap Kematian Petinju Akibat Kealpaan Penyelenggara. Al-Jinayah: Jurnal Hukum Pidana Islam, 1(1), 129-167.

Hadi, U. (2009). Pertanggungjawaban pidana terhadap kematian petinju akibat kealpaan penyelenggara: studi komparatif antara hukum pidana KUHP dan hukum pidana Islam (Doctoral dissertation, IAIN Sunan Ampel Surabaya).

Imtiyazi, M. S., Kumaidah, E., \& Purwoko, Y. (2018). Perbandingan Parameter Fungsi Paru Atlet Putra Cabang Olahraga Individu Dan Beregu Di Pusat Pendidikan Dan Pelatihan Pelajar Jawa Tengah (Studi pada Cabang Olahraga Tinju dan Sepak Takraw) (Doctoral dissertation, Faculty of Medicine).

Jako,P.(2002). "Safety measures in amateur boxing". British journal of sport medicine. :394-395 doi:10.1136/bjsm.36.6.394.

Kristanti, C. M. (2002). Kondisi fisik kurang gerak dan instrumen pengukuran. Media Penelitian dan Pengembangan Kesehatan, 12(1).

Leo syahputra. (2008). "Kamus besar bahasa indonesia”: Lima Bintang

Moeslim, Mochamad. (19680. "Test Pengukuran Dalam Olahraga”: Yogyakarta: Sekolah Tinggi Olahraga Yogyakarta.

Maliki, O., Hadi, H., \& Royana, I. F. (2017). Analisis Kondisi Fisik Pemain Sepak Bola Klub Persepu Upgris Tahun 2016. Jendela Olahraga, 2(2).

Rosiana, A. M. (2013). Hubungan antara kondisi fisik rumah dengan kejadian tuberkulosis paru di wilayah kerja Puskesmas Kedungmundu Kota Semarang. Unnes Journal of Public Health, 2(1).

Sudjana. (2005). "Metode Statistika”. Bandung: Tarsito. 
Saputra, N., \& Aziz, I. (2020). Tinjauan Tingkat Kondisi Fisik Pemain Bolavoli Putra Sma 2 Pariaman. Jurnal Performa Olahraga, 5(1), 32-38.

Simatupang, N. (2015). Pengaruh pemulihan pasif dan pemulihan pasif dengan manipulasi effleurage terhadap kekuatan otot lengan. Jurnal Ilmu Keolahragaan, 14(1), 15-23.

Saripin, S. (2017). Tinjauan vo2max pada atlet tinju putera dan puteri club denpal boxing camp Pekanbaru (Doctoral dissertation, Riau University).

Yudiana, Y., Subardjah, H., \& Juliantine, T. (2012). Latihan fisik. Bandung: FPOK-UPI Bandung. 